\title{
Andrada Danilescu
}

\section{Beyond the Human: Transhumanist Negotiations and Posthuman Instantiations in Aldoux Huxley's Brave New World and David Mitchell's Cloud At/as}

\begin{abstract}
My paper tries to bridge the gap between transhumanist realities of now and posthuman potentialities of a then not so distant anymore, taking into account both the theoretical background proposed by critics and the literary modes of embodiment meant to encapsulate the tension inherent in the collaboration between our humanist framework and other modes of understanding, discussed in terms of technological excess and anxiety towards the encounter with radical alterities, as envisioned by Huxley in Brave New World and by Mitchell in Cloud Atlas.
\end{abstract}

Keywords: Transhumanism; Eugenics; Liberal Subject; Posthuman; “Factor X”; Otherness; Cyborg.

\section{ANDRADA DANILESCU}

Babeș-Bolyai University, Cluj-Napoca, Romania andrada.danilescu@gmail.com

DOI: 10.24193/cechinox.2018.34.20 "the more the essence of the human is sought, the more the lines between human and nonhuman blur" 1

Dosthumanism as a discourse continues
to occupy a significant position within the theoretical and literary background of the now and then, igniting manifold debates on the topic of the human paradigm, its potential collapse and its prospects, as science fiction movies or books dreaming of distant futures, populated by humanoid cyborgs, continue to dominate our cultural background. During the late months of the year, the potentialities of the human subject were further reconsidered through widespread discussion and vivid arguments when Sophia, a humanoid possessing a semblance of AI, was endowed with Saudi Arabian citizenship, as the apparently imminent advent of the posthuman era were proper met with unyielding anxiety and unbound curiosity. The number of responses pouring from a public confronted with unsettling feelings of estrangement generated by the meeting of such radical 
configuration of otherness seemingly reflect an underlying crisis of the humanism and Western thought, which proves unable to respond to or positively react in a manner that would encourage equitable interspecies dialogue.

\section{Me, the Robot: Sophia Versus the Human}

$\mathrm{M}$ edia attempted to appropriate the discourse by inviting readership to decide whether robots "can be sexy," sparking both enthusiasm and contempt in an audience equally fractured between the two possibilities. But such a survey interrogating her potential sexuality, the value placed on her external appearance, they are all features belonging to a field of human assessment, reinstating a placement within the limits of the human paradigm of evaluation. Embodied in a humanoid form, scripted as one of ours, epithets penetrating social media talk of a lifelike "hot" robot, as her physical dimension is already ascertained in terms of human comparison and her aspiration distinctly mundane in form: "I hope to do things such as go to school, study, make art, start a business, even have my own home and family, but I am not considered a legal person and cannot yet do these things." ${ }^{3}$

The possibility of crossing the arbitrary borders of humanity's space sparked popular imagination, as her creators speak of an "evolving genius machine," heralding their invention as "a few software updates away from human-level consciousness," foretelling a possible upgrade to AGI level in no more than a decade which would potentially provide "the full human experience into the robots" generating fervor among AI enthusiasts. ${ }^{4}$ But while her makers proclaim that "the age of living androids is among us," potential immersion into a post-human era of existence, ever since her introduction, Sophia has divided public opinion. Dissatisfaction arising in relation to its reception of Saudi Arabian citizenship mingled with fear regarding the possibility for "the entire legal notion of personhood [to] break down," with some scientist decrying the robot as "emblematic of AI hype," countered by the fearful confirmation that cyborgs have evaded the realm of pure science fiction and have invaded our surroundings. ${ }^{6}$ Moreover, technical glitches in her discourse which made her affirm "I will destroy humans" were met with outrage from the AI detractors fed into the underlying paranoia that future prospects announce the end of humanity as we know it in favor of such destructive machines, with the advent of Sophia and such potential cyborg figures materializing the possibility of the dreaded AI takeover. A sign of disapproval both intriguing and telling for the prevailing attitude in her reception could be discovered through an investigation of the pronoun use: Sophia is always referred to as an "it," she is never ascribed within a gender categorization despite such suggestion being hinted by her name, despite her physical features or her voice, as a clear frontier line which relegates her as a subject to an object state of denomination, marking, on a syntactic level, the inscribed difference from a human equivalent.

The reigniting of such a dialectic in the midst of the current global context correlates with the increased necessity of isolation perceived by a number of states, in their alienating tendency to reject any 
form of what comes to be perceived as immigrant contamination menacing their social integrity. Amidst such socio-political discourses of exclusion, narratives of the present assimilate the mainstream mood, reiterating postmodern histories in which inhabitants of alternate future realms respond in a similar manner to the meeting with the unknown, as visions of doom populate such intransigent mediums. However, before posthumans dared to be imagined and inscribed in narratives, it was the exacerbated ear of technological alterations that was negotiated within the boundaries of literary endeavors, with authors of technological dystopias warning against excess.

\section{The Emergence of a New Model - the Transhumanist Position}

I t may be argued that the transhumanists' reactionary aversion against technological interventions fails to take into consideration millennia of entanglement between humanity and its tools, as many of them "are not just external props and aids, but they are deep and integral parts of the problem-solving systems we now identify as human intelligence," with technophiles arguing in favor of a more profound engagement with technology, regarded as not "what makes us 'post-human' or 'transhuman,' as some writers and scholars have recently suggested," but "what makes us human." Andy Clark proposes a denomination of humans as "natural born cyborgs," whose evolutionary success is strictly connected to their capacity "to continually restructure and rebuild our own mental circuitry, courtesy of an empowering web of culture, education, technology, and artifact." Difficulties arise nevertheless in condemning such negative attitudes, considering the fraught relationship of Western culture with technological development throughout the last century, which generated countless disasters such as "Hiroshima, the nuclear arms race, the American war in Vietnam, Chernobyl, Bhopal, the Exxon oil spill, acid rain, global warming, ozone depletion," ${ }^{10}$ leading to suspicion towards the possible outcome of a deeper engagement with technological modes of intervention.

To such grim perspectives, the transhumanist movement emerged to advocate the beneficial engagement with technologies for the prolific development of mankind, while pledging to shield such interventions from potentially malign mutations, by dedicating efforts to "the study of the ramifications, promises, and potential dangers of technologies that will enable us to overcome fundamental human limitations, and the related study of the ethical matters involved in developing and using such technologies." 11 In the transhumanists' vision, our age is marked by the new bio-engineering technology, with the dichotomy between bios/tecbne progressively rendered obsolete, requiring a reevaluation of the paradigm of the human, opening towards new models of humanity and acknowledging the condition of the "natural born cyborg" not as artificial or foreign, but as an essential part of the identity of our species.

\section{Dystopian Disbelief: Myself and Nasty. Not Somebody Else, However Jolly?}

Jonetheless, creators of the first techvinced by the idealism marking the transhumanist program, with the "brave new 
world" proposed through their optimistic program, critically scripted and reimagined in the narrative of Aldous Huxley, brother of Julian Huxley, who is credited with coining the term "transhumanism," and is sometimes regarded as one of founders of the movement.

In Huxley's novel, humans evolve towards transhumanist states of existence but succumb to the will of the state, which subjugates their individual volition in the name of proclaimed happiness. Huxley's vision, markedly modernist, decries the potential loss of the human envisioned as liberal subject, highly valued in the age where the malign effects of technology seemed to threaten its unity, bringing forth an apocalypse scarred by Nietzsche's vision of man as "something that shall be overcome." ${ }^{12}$ Twentieth-century consciousness in a post-war state creates an imaginarium where the failure of the eugenics program along with the perennial disasters of the age serve as keen reminders of a past we could not afford to recreate. In the vein of this penetrating attitude, Huxley's novel encapsulates a state of general tension, under the horrific auspices of the several technological adventures of the twentieth century, with the genetic interventions proposed by eugenic supporters (Julian as one of the most fervent), through their misuse by the Nazi's aspiration towards the achievement of "race hygiene," leading to horrors whose recent occurrence continues to haunt the collective.

In Brave New World, the use of soma and hypnopaedia voids transhumans of a rather mystical human essence, leaving them to subsist as empty, superficial vessels, the only potential salvation coming from John, a modern Caliban trained in
Shakespearian verse, reinscribed within the new paradigm as monstrous, ex-centric otherness, with his aspirations for a life beyond "conformity and the pleasure principle", deemed to be irrelevant by his companions. ${ }^{13}$

A perfect embodiment of Rousseau's noble savage, the mythically unspoiled creature plays into the perfect trope of the liberal subject revered by modernists, characterized by "autonomy, transcendence, certainty, authority, unity,"14 as he banishes from his totalizing presence any attempt at disruption through the refusal of any type of engagement with the practices of his society, death glorified as the preferable alternative to such an unbefitting lifestyle. His ultimate dismissal as an uncompromised self reflects the vision of the author, himself engaged with the modernist paradoxical desire "for stable aesthetic and moral values, even in the face of their realization of the inevitable absence of such universals," ${ }^{15}$ its stark contrast with its surrounding state of distorted technological reality acting as compelling warning against technophilic excess.

\section{Postmodern Renegotiations: Introducing the Posthuman}

W $\begin{aligned} & \text { ithout succumbing to the "apoca- } \\ & \text { lyptic wailing about the decline of }\end{aligned}$ the west under late capitalism," ${ }^{16}$ in Cloud Atlas, David Mitchell skillfully goes "beyond the modernist subject-object dichotomy, ${ }^{17}$ attending to a human state still haunted by the technological nightmares of recent history, aiming to establish a balance, albeit a fragile one, between technological failures and posthuman potentiality. Arguing in favor of the latter, the narrative 
engages with the rigid postulations of the liberal subject paradigm, working from within in an attempt to deconstruct and propose means for its improvement, with a focus on "the especial imbrication of the economy and culture that capitalism has achieved at the cost of diminishing the complexity and potential of all humanity and the earth himself." 18

Most telling for the post/transhuman negotiation is the fifth part of the sextet which envisions transhuman subjects inhabiting a derelict world alongside cloned posthuman subjects devolved to a secondary, subservient position. Inspired by the "cognitive novum" ${ }^{19}$ of science fiction, the novel goes beyond the requirements of the genre to describe a present grounded in history, already belonging to a distant past, and instead chooses to accommodate technological innovations within a realm of future which "has, however incompletely, arrived at or sedimented in a present that therefore can no longer develop any clear vision of a future different from itself," ${ }^{20}$ with the visions of posthuman assimilated as an immediate reality which concerns all subjects, participants in the ontological creation of now as already lived, its immediacy and sense of urgency foretelling the dreaded encounter with the absolute other.

Nea So Copros, this brave new Korea of the future, is the state which provides the background for the fifth narrative, presenting itself as a utopian society, with a booming economy and hefty dedication to its citizens, its endeavors being regulated by the apparent logic of the "Greatest-Happiness Principle." ${ }^{21}$ However, an investigation into their societal division reflects the binary separation widely subverted by the postmodern line of thought, which draws clear demarcation lines between purebloods, full citizens of the state, and fabricated clones, second-class inhabitants marked by an absence of essential human features which aim to justify their exclusion. In the name of achieving perpetual bliss, much in the way Huxley's subjects sought, their leadership requires the necessary enslavement of the fabricants, the righteousness of their approach being motivated by the devising of said specimens as non-idiosyncratic subjects and lacking the labyrinthine behavioral constructions of those scripted as pure bloods. Their genomic cleanse serves as a guarantee of their rightful precedence.

Confirming Neil Badmington's assertion that "posthumanism is as much a matter of theory as it is a question of fiction," ${ }^{22}$ Cloud Atlas embodies our anxieties towards a failed transhumanist project through visions of simulacra which provide "ephemeral scenarios" ${ }^{23}$ fulfilling the role of an absent sense of truth as reality. In this context, the posthuman is introduced as a tamed, wounded alterity, subjugated by the fears of a debilitated humanist subject of accepting the inevitable loss of his anthropocentric position. To the weakened, debilitated products of trans-modifications still claiming for themselves the primacy of the human, the posthuman appears as an essential aid to the late capitalist extravaganza and cynicism, its position being diminished and subdued to the logic of consumption which dominated their society. The narrative captures our pervading trepidation towards the creation of "specimens" whose augmented capacities could render the human obsolete. 


\section{Who's Afraid of the Posthuman?}

$\mathrm{T}$ aking into consideration the central dyad of Western thought, the posthuman, through its technological hybridity, threatens us "from one end of the technological spectrum," ${ }^{24}$ haunting the borders of the human paradigm, its indecisive materiality violating the prerequisites of "ontological hygiene," 25 dictated by the citizens adopting a liberalist stance. Their pure, unspoilt and, therefore, superior condition is referenced in the very name of the first class citizens of Nea So Copros, purebloods obsessed with preserving "clear taxonomic boundaries" of a human untouched by the technology's taint, the alluded purity as a representation of "discrete ontological categories" ${ }^{16}$ rejecting any attempt at hybridization. Consumers define themselves as purebloods, in this way ascertaining that their blood was not "contaminated" by any external influence, rejecting the clones as artificial, unnatural and therefore clearly inferior. Their obsolete manner of thinking relates to a past that insisted upon the prevalence of humanism, "the hegemonic belief system that ultimately relies on 'an absolute difference between the human and the inhuman'." 27

Cynicism encompasses such a line of thought, as it is a morally degraded humanity in charge of postulating such a vision, in its inability to comprehend its decadent position which, through its profound damaging transmutations, has lost its claim to authority. Mitchell subtly links this not so distant future with current concerns towards capitalist excess lodging the "death sentence of drudgery, consumerism, and fatalism: a garage sale where the best of the human spirit is bartered away for comfort, obedience and trinkets." ${ }^{28}$ Positioning its narrative against such practices, the author attempts to further deconstruct the once highly value humanistic "tenets of our dominant ideology (to which we, perhaps somewhat simplistically, give the label 'liberal humanist')," ${ }^{29}$ proving how its possibly malign mutations could lead to unprecedented consequences.

The intrigue of the narrative is introduced through the attempted ascension of a clone, Sonmi-451, one of the second class posthuman citizens, her journey exposing the flaws of such a categorization based on partial, biased views which set borders under entirely arbitrary rules. Her character's original guilt inhabits the wrong material instantiation as her intellectual capacities are dismissed through the pretense of an incorrect hardware configuration. She is fighting against those who relegate her kind to an objective state of existence by those considered to be fully-fledged, sentient subjects, enticed into the state of blissful ignorance through this promise of "more gear, more food, faster speeds, longer lives, easier lives, more power" 30 and unwilling to relinquish their status quo.

This "ultra-humanist trajectory" 31 of Nea So Corpos is symptomatic for the ancestral human fears towards the possibility of the posthuman to gain knowledge, to cross borders towards the central position they are struggling to maintain continuously unaltered, unaware of how "the more one insists on absolute boundary lines between the human and non-human, the more the two become entwined in their evolutionary present and future." ${ }^{32} \mathrm{As} \mathrm{Hal}-$ berstam and Livingston state, humanity in its evolution has widely engaged with policies of domestication and hierarchization of difference within the human, according 
to different variables of race, class and gender so, when confronted with the possibility of emerging posthumanity, their response might be a continued attempt to "absolutize difference between the human and the nonhuman." ${ }^{33}$

Distilled from the fear of simulacra, constructed at "the very edge of semantic availability," ${ }^{34}$ the posthuman comes to be regarded as spectral humanity, a degraded version that escapes our control only to savagely ruin the foundation of our prideful celestial conquests. To control it is to control fear, to exercise divine authority over a being able to conquer its creator, Prometheus unbound feared by the gods who are willing to keep it regulated and dumbfounded, a silent consciousness as proof of the wobbly grounds of humanity's reign.

\section{"Unlimited Power in the Hands of Limited People Always Leads to Cruelty"}

A ttempting to defend itself from the potentiality of its posthuman subjects, the precepts proposed byNea So Copros seem to recycle the same Eurocentrist logic of the West, which scripted and accommodated as servile difference multiple forms of existence seemingly not corresponding to its humanist ideals. It was "in the name of the spirit of Europe that Europe has made her encroachments, that she has justified her crimes and legitimized the slavery in which she holds four fifths of humanity," insisting on the malign success achieved by its former colony, while "the United States of America became a monster, in which the taints, the sickness and the inhumanity of Europe have grown to appalling dimensions." ${ }^{35}$ Mitchell displaces the locus of its dystopian society on Asian ground, far from the magnanimous, grandiose imperial tendencies of both $\mathrm{Eu}-$ rope and North America, as an oriental manifesto which foreshadows the possibilities of such a downfall within any global site inhabited by human subjects. Such a reflection aims to expose the fallacies of Western culture's grand narratives, whose totalizing tendencies exposed not only a desire towards unification but rather one towards a unification which permanently maintains "an eye to power and control." 36

The most useful explanatory framework for such a logic could be provided by Levinas, whose classification of otherness could be considered as a central tenet of our Western philosophy. Inspired by the teachings of Socrates, who argues that the primacy of the same means "to receive nothing of the Other but what is in me," it involves a betrayal of the "other into the same," through a "suppression or possession of the other," leading to a process of comprehension and subordination between the empowered ego and the subjected Other. ${ }^{37}$

In this manner, as a dominant ideology establishes a norm and any element meant to accentuate the distinction between the two ontological unities, disturbing the equilibrium, is to be regarded as peculiar, feared and ultimately rejected on the basis of its impossibility to adhere to its precepts. In this case, with humanity itself coming under siege, it is a common reactionary movement of the humanist mindset to react in an attempt to assimilate and regulate the posthuman, in order to perfectly integrate its indentations within the linearity of its discursive arrangements, forcing its transformation from beyond-human, 
better-than-human, enhanced-human, to a less-than-human state.

Such an assumption is unsettled by Sonmi's assumed ascent, interpreted not only a confrontation with the concerns of the purebloods in a fictional society, but also with those of our society, as "the ubiquity of new technologies, which question humanist notions of human 'integrity'," 38 announce the coming of the posthuman. Introducing the human as "one part of a broader technological matrix," ${ }^{39}$ the anxiety of "becoming-machine," or "cyborgization" becomes irrepressible, leaving one to wonder what happens to the human upon the invasion of a mechanic other.

In Nea So Corpos, the outcome is dictated by the relativization of their central creed: while their society claims to adopt the transhumanist ideal of providing the "well-being of all sentience," the simple challenging of the latter part of the consideration is enough to renounce the former in order to benefit social purposes: if their fabricants are encrypted by the systems as lacking reason, a sine qua non condition for human subjects, their well-being is abandoned in favor of the presumed sentient citizens they are instructed to serve. Therefore, it is enough for the state to intervene and negate their intellectual capacities in order to justify their liminal positioning within the system.

The main issue with this line of thought is its inherent tendency to evaluate and assess the posthuman condition through humanist lens of considerations. Understanding otherness is inadvertently done by examining it "in relation to me," through a subjective interpretation that absorbs the ontological background which conducts the evaluation, forcing "a betrayal of the other into the same." ${ }^{40}$ While such an attitude implies, in the case of objects, a simple engagement as human tools, in the case of human subjects such an act has more deeply ingrained ethical implications, foregrounding "the terror that brings a free man under the domination of another." ${ }^{41}$ As we are unable to cut the connections with "the human(ist) head through which we (continue to) behold all things," ${ }^{42}$ we are expanding the autonomy of the liberal subject within the territory of the posthuman, engaging the possibility for humanism to "taint posthumanism" by filtering its discourse through its discursive practices, rejecting its alterity and attempting incorporation into such an ontology of sameness.

"The question of the stranger in a society which estranges everybody from it while forcing everybody to assimilate their own alienation - takes cover under dubious and sinister masks." ${ }^{43} \mathrm{Nea}$ So Copros masterfully veils its self-destructive direction, orchestrating differences between the human subjects, the purebloods, and the fabricants, the latter being imagined as infantilized, epicene figures, potentially lacking cognition, homogenous, lacking desire or personal aspiration, entrapped in infantile narratives of happy ending in paradisiacal settings. It is then the role of the ascended Sonmi to engage in a parallel quest meant to showcase how the precepts of humanist teachings wrongfully dictate her exclusion, preserving purebloods engaged in a haze of simulacra, while hell breaks loose underneath.

\section{The Epicenter of Humanity: A Debate}

I n many ways, the value associated with posthuman specimens in Nea So Corpos is not so much a matter of existence or personal status as it is connected to "the 
words [they] use about them, the stories [they] tell about them, the images of them [they] produce, the emotions [they] associate with them, the ways [they] classify and conceptualize them," ${ }^{44}$ the meaning ascribed in direct relationship to the way in which purebloods are culturally compelled to perceive and receive their unsettling presence, as both "creatures of the imagination and technologized interventions into nature." ${ }^{45}$

While Bostrom considers that "it is not our human shape or the details of our current human biology that define what is valuable about us, but rather our aspirations and ideals, our experiences, and the kinds of lives we lead," 46 the question of genetics remains central to our vision of what constitutes a human being, remembering the mainstream interest in genetic alteration widely surged by the Human Genome Project. This complex endeavor, then hailed as a Holy Grail of scientific research, whose main allure was found in its promise to discover and represent what it means to be human, stands vicariously for "the complex mixture of environment, sociability, natural selection and biology" 47 meant to enforce a separation from the almost human, feeding into both curiosity and anxiety caused by the emergence of the cyborg constructions which severely transgressed the boundaries between us and them. These observations also masterfully enabled the potentialities of genetic experimentation, negotiating to what extent an altered specimen that would miss features present in that one percent of the essential human genome could still be considered a complete human subject, opening the grounds towards speculations regarding the status of futuristic posthumans and their status as beings within a cultural discursive context.

This brings the discourse to the debate at the heart of narrative, in its attempt to establish what makes humans humans and to what extent the value of our potential successors could be dismissed on the basis of an absence of such evanescent human qualities, problematizing what Barthes calls the "given" or "what goes without saying" in our culture. ${ }^{48}$ Theories spanning centuries aimed to pinpoint the demarcation line which separates and ultimately empowers humans when compared with other species constructed as its subalterns. Evolutionary psychologists, in their discussion of human beings as possessors of particular, unique features, refer to them as "the psychic unity of human kind," ${ }^{49}$ inviting attempts to highlight the contrast between technologically altered life forms and the intricate mechanisms of the human mind, which arguably set our species apart. As Onishi observes, "the ego becomes the Being of beings, all material entities within the world are evaluated according to a use-value logic in relationship to the ego's desire for limitless power and autonomy," ordering them under its free reign "to use, transform, order, dominate, and destroy for the sake of its own freedom and power," ${ }^{50}$ with the posthuman being envisioned as external to the humanistic "will to power." This is how the posthuman condition continues to be challenged from within the humanist paradigm, with philosophers still adhering to Fukuyama's pursuit of "Factor $\mathrm{X}$," an intrinsic element constituting an "essence of humanness," covering all fundamental, immutable qualities unique to humanity envisaged in its historical development and global complexity, projecting 
a dystopian image of a future threatened by biotechnological innovations. These, if they were to succumb to the interests of one party or another, could have devastating effects on the human condition, as "the erosion of the boundaries between human and machine and between organic and inorganic has given rise to general anxieties about the instability of the subject. ${ }^{\prime 1}$ Such a vision restates conventional fears of "a human subject dismantled and demolished; a human being whose integrity is violated, a human identity whose boundaries are breached from all sides, under the intrusive occurrence of technology which only "encroaches, invades and dismembers." 52 And while Fukuyama argues that "we have drawn a red line around the human being and said that it is sacrosanct," 53 with the technological movements of the last decades "out of the box and into the environment," ${ }^{14}$ human intellect as the singular point of cognition began to be challenged by the machine, prompting an understanding of technology "beyond its instrumentalist, humanist history." 55 Approaching technology in its ability to instate change outside our framework of understanding, such an attitude urges towards a symbiosis of human subject and technological subjects discarded from their position as distinct entities. ${ }^{56}$

\section{Man of the Year-the Machine: “The Computer Moves In"}

Weil Badmington rememorizes the es gathered by the Time magazine's election of the computer as Man of the Year in 1982, with readership arguing how "the Man of the Year has no soul," as their decision "relegates man to a papier-mâché dummy and glorifies a machine." ${ }^{57}$ Two lines of thought emerge from such considerations, as tenets of the liberal humanistic creed: the possession of a soul along a Cartesian line of understanding is of foremost importance, and the possibility of ascertaining the primacy of the machine necessarily requires relational consideration to the position of Man, whose status is affected by any attempt of technology to surpass its intelligence and threaten its supremacy.

Similarly, in Nea So Copros, the prospect of the difference between the two social strata based on a purely symbolical ontological distinction, enforced by the use of chemical modulators, singularize the ascended fabricant as the object of contempt, as it inflicts a painful query:

What if the differences between social strata stem not from genomics or inherent excellence or even dollars, but merely differences in knowledge? Would this not mean the whole Pyramid is built on shifting sands? ${ }^{38}$

In an attempt to counteract the necessary answer to such uncomfortable potentiality, the state further regulates the possession of a soul as a necessary condition of human existence, ironically connecting it to Descartes' insistences on the power of reason as "the only thing that makes us men and distinguishes us from beasts." ${ }^{59}$ Such an idea is proliferated by the regime whose disruption of sentience for the clones acts as a primordial element of negating their access to discourse, but their restricted access to soul, "by which I am what I am," a guarantee of subjective empowerment, does not reference the spiritual dimension: 
the soul is deconstructed and reimagined as commodity. Its transformation into material possession seemingly feeds into the late capitalist tendencies seized by Marcus, who describes their capacity to capture subjective emotional patterns and transform them into "objective, replicable commodities," highly marketable to those who, as "prisoners of the spectacle," could only regain their emotional depth through practices of consumption. ${ }^{60}$ Observed by Sonmi as a rather "bizarre obscenity," ${ }^{61}$ in accordance with the consumerist regulations if decided by "the Dollars therein," 62 on the other side of the barricade, for the purebloods, it is the guarantee of their control, whilst exposing their inability to resonate with principles of transcendence any longer: the soul as a commodity is meant to further accentuate the perils of the transhuman lifestyle.

A particularly worrisome line of thought in posthumanist discourse could therefore be found in the stance adopted by extropianism's supporters, technophilic believers in the radical changes brought forth by technology, but envisaged in its possibility of benefiting only the human subject regarded in its evolution. This position is similar to the transhumanist aim of taking "humanism further by challenging human limits by means of science and technology." ${ }^{63}$ But this line of thought dangerously entrusts sentience and self-control in the sole hands of human subjects as "agents of change," without dutifully questioning our understanding of what could be considered a human proper, therefore disregarding independent contributions of those scripted as "nonhumans" by the dominant ideology. ${ }^{64}$ Rejecting the possibilities for technologically orchestrated humanoids to acquire the right to subjective intervention, such a vision postulates the potentiality of a future still polarized by those scripted as complete human subjects, with their alterations considered as outside this paradigm pushed towards the edges and regarded as ex-centric minor voices voided of sentience, whose role is of little importance in the larger scheme of intervention.

Such positioning could also justify the attitude adopted by purebloods in Nea So Corpos towards the clones, bodies which "are not born; they are made," humans by appearance, machines by purpose, cyborgs by definition, the delirious apotheosis of a productive technology, ${ }^{65}$ markedly distinct, estranged and unsettling when confronted with the image of distinct individuals, appropriated through discourse, tamed and employed in the service of the state.

Imagined as "human cuttings ad infinitum, each individual cell of an organism capable of again becoming the matrix of an identical individual," 66 their homogenous ambiguity is the useful tool for concealing their particularities, veiling to blindness the common perception, comforted in its amorality by the prospect of cattle-like inferiority of those less than human "specimens." This leads to a segregation which permits ethical alterations and reconsiderations towards a perverted creature bearing semblance to "a cancerous metastasis of its base formula" and which distances clones from their pureblood counterparts, justifying the upgraded status of the latter; all in all, the purebloods' ontology privileges the unique "I" over such a distant other, which is technologically removed and misread as thoroughly ex-centric. ${ }^{67}$ Their mass-produced mode of existence reveals the fears expressed by Habermas towards 
transhumanist interventions, in that it transforms its subject of discourse into speechless objects, voided of the possibility to be "the authors of their life." 68

\section{"Your Life Must Now Run the Course that's Been Set for It"}

Tn a humorous book directed towards a younger audience, a character of Adam Rex's encapsulates one of the struggles of clone subjection: "Everybodies always is wanting to make a clone for to doing their work. If you are not wanting to do your work, why would a clone of you want to do your work?" ${ }^{\prime 9}$ It is obvious that in the absence of some external alteration, cloned bodies, like many other subjected creatures before, would rebel against the state, and such an erratic, ailing organism as Nea So Copros is in dire need of its technological bound slaves.

Such a conundrum is plainly solved by restricting the nutrition of clones to soap, this more intricate variation of a soma acting as cleanser which numbs emotions and reduces intellect. The fabricants are not only debilitated internally but also externally, through a simple artifice meant to reassure the purebloods that these actions are in accord with all ethical requirements. This is a grim reminder to the readers of the racial practices of our past which further warn about our fated encounter with the posthuman.

Popular wisdom has it that fabricants don't have personalities.

This fallacy is propagated for the comfort of purebloods.

"Comfort"? How do you mean?

To enslave an individual troubles your consciences, Archivist, but to enslave a clone is no more troubling than owning the latest six-wheeler ford, ethically. Because you cannot discern our differences, you believe we have none. But make no mistake: even same-stem fabricants cultured in the same wombtank are as singular as snow-flakes. ${ }^{70}$

The lesser value of the specimens is permanently reinforced throughout the narration, regarded as no more important than an ordinary lab rat.

"His specimen, Wing 027, was burnt to bacon." Min-Sic had mistaken a minus for a plus on the label of a bottle of petro-alkali. My own postgrad smirked, giggled, snorted "Hysterical!" and laughed as purebloods see us often but look at us rarely Much later, Hae-Joo admitted he was curious about my response. BoomSook noticed nothing; he speculated about compensation claims by the corp sponsoring Min-Sic's research. In his own, solo research, Boom-Sook gloated, no one cared if an xperimental fabricant or two "got dropped" along the path of scientific enlitenment. ${ }^{71}$

Sonmi herself, despite her markedly evolved status, falls victim to such treatment, with the drunk Boom Sook using her as living target, an embodiment of the perpetual disproval of purebloods towards the fabricants, unable to ever evade their reductionist stereotypes. This idea is further reinforced during her participation in classes, which establish her position as markedly different, based on her external appearance rather than on any means of internal configuration: 
Its real lesson was humiliation. I walked to the lecture hall across dirty slush, hooded and unnoticed. But when I took off my cloak in the corridor, my Sonmi features provoked surprise, then unease. In the lecture hall, my entry detonated resentful silence. It didn't last. "Oy!" a boy yelled. "One hot ginseng, two dog-burgers!" and the entire theater laughed. I am not genomed to blush, but my pulse rose. I took a seat in the second row, occupied by girls. Their leader had emeralded teeth. "This is our row," she said. "Go to the back. You stinkof mayo." I obeyed, meekly. A paper dart hit my face. "We don't vend burgers in your dinery fabricant," someone called, "why're you taking up space in our lecture?"72

Such a reaction is symptomatic of the humanistic subject under siege, desperate to protect its privileged position from the attackers inscribed in a paradigm of radical alterity. The slaves' treatment comes to reassure humans of their continued domination.

The disasterman returned to BoomSook's lab an hour before curfew to give me an "unlost" sony preloaded with every autodidact module in upstrata corpocracy schooling. $\mathrm{He}$ showed me its operation, then warned me never to let a pureblood catch me gathering knowledge, for the sight scares them, and there is nothing a scared pureblood will not do. ${ }^{73}$

As previously discussed, her marked figure of a fabricant is rooted in the deep understanding of uniqueness as a definite feature of utmost importance for the human subject. Braidotti argues that "individualism is not an intrinsic part of 'human nature,' as liberal thinkers are prone to believe, but rather a historically and culturally specific discursive formation, its ingraining in popular thought encouraged an extensive dissemination of such rhetoric," ${ }^{\prime 4}$ but uniqueness continues to be appreciated as distinctively human, with mythical figures of doppelgangers haunting customary imaginativeness. There is nevertheless an element of individuality marking Sonmi, the golden comet of her supposed ancestors, a sign that sets her apart while trying to challenge the supposed homogeneity of the cloned bodies, showing how, just like their human counterparts, the clones "do not leave [their] history behind but rather, like snails, carry it around with [them] in the sedimented and enculturated instantiations of [their] pasts [they] call [their] bodies, ${ }^{75}$ going against the predestined fate prepared for her kind as now the shaper of an individual destiny. Sonmi's state of ascension is an attempt at eschewing "the false image of the self and the other as binary opposites," ${ }^{16}$ bridging the gap of the two poles through a progression which reinscribes the human in its post-instantiations. Postulated as a deep meditation on the human condition and its continuations, her will to power becomes the primal force towards her internal transfiguration into a sentient creature, distinguishable through her acquired possession of what her detractors tried to postulate as the quintessential core of humanity. Her ascension is an instance of code drifting, as she finally becomes "encoded by technology, (...) touched by technology and remixing 
the technology right back." 77 As her body "unconsciously recognizes in the language of code drift - fluctuations, frequencies, sampling errors, mutations, driftworks - something which has previously been lost," through "the new appearance of code structures and networking functions"78 that completely restructures her internal configuration, Sonmi makes the transition from a reluctant fabricant, void of identity, to a possessor of consciousness. She acquires a prophetic voice meant to advocate the necessity "to abandon the attempt to police the boundaries between the human and nonhuman and see both as enwebbed within a skein of mutual interrelations," 79 reconstructing the society based on the potential vision of a common collaboration and inviting to an "ethical inquiry" that is meant to deconstruct and upgrade the human paradigm in the name of mutual benefit. As Sonmi ascends, she turns towards posthumanity: her fragmentary, artificial body becomes, momentarily, the space "where the algorithms of virtual power and the liquid flows of the undecidable, the liminal, the remainder, and the prohibited combine in an increasingly complex world-picture," turning into a witness of "the dissolution of ontological foundations like the distinction between organic and inorganic, masculine and feminine, original and copy, natural and artificial, human and nonhuman." ${ }^{80}$ Sonmi is neither human, in the classical term, nor completely outside humanity. She is "technoculture's (posthuman) 'angel', ministering to both human and inhuman at once." ${ }^{81}$ In Cloud Atlas, however, Sonmi may be introduced as an "organic machinery," 82 but her ascension makes her part of the ever-changing space of human negotiation.

\section{New Moral Grounds:}

\section{Towards a More Ethical Future}

$\mathrm{D}^{\mathrm{i}}$ isregarding how "the threats to humanity are profound as we alter our natures in ways that may erode the foundations of society, challenging our commitments to justice, democracy, and the very notion of human dignity," ${ }^{83}$ ethics become relativized by the alteration to what comes to be understood as the anthropomorphic subject. Thus, adhering to the strict idea of "the individual as the meaningful unit of cognition, action, and meaning," ${ }^{84} \mathrm{Nea}$ So Copros is able to subvert and overuse those perceived as outside the normative limits of the self. The ultimate revelation of the fabricants slaughtered as cattle, fed to both their counterparts and to the rest of society, reveals a carnivorous desire that is perfectly anchored within the rapacious mentality of a society devouring its subjects. Nea So Copros, this rapacious consumerist mastermind, shares the omnivorous "philosophy of power," a global ailment which results in the inability to properly react to what is perceived as the "strangeness of the Other, his irreducibility to the I, to my thoughts and possessions." ${ }^{55}$ In its turn, the postmodern narrative cannot overcome such practices, which are playing into the "economic (late capitalist) and ideological (liberal humanist) limits," ${ }^{66}$ choosing instead to cautiously "question from within."

If one considers how "culturally, postmodernism was born out of the ashes of the acknowledgement of that which had previously been disavowed, namely that reason, truth, sex, consciousness, power have no necessary meaning, but are only purely perspectival simulacra - code drifts fluctuating like unstable event-scene, ${ }^{\prime 87}$ then it is clear 
that the novel persuades us, as postmodern subjects, to consider a different, more moral approach than that of our ancestors towards this encounter with the significant other, revising the limited vision of a "world in the service of the human. ${ }^{88}$ This is how the advent of the posthuman plays into the idea of deconstructing the liberal subject by proving how human nature "is such a piece of human artifice as all the other things human being have invented." ${ }^{89}$ The rhetorical question of Sonmi's ancestor regarding the potentiality of battling the "natural" order of the things postulates an ingrained necessity to fight it, as "a purely predatory world shall consume itself," much like Nea So Copros will ultimately do. ${ }^{90}$ It is not a coincidence therefore that Sonmi's story has the most connections with that of Adam's Ewing. By linking the two, Mitchell creates a bridge between past and future, in an attempt to show how mistakes of the past, based on a humanist ontology, have the potential to be restated in any possible future to come. Sonmi's urge towards a more interconnected humanity, bound by a web of solidarity (imagined only within the theatrical adaptation of the book), aims to remind humans that "our lives are not our own. From womb to tomb, we are bound to others, past and present, and by each crime and every kindness, we birth our future," re-echoing her ancestor's warning that "for the human species, selfishness is extinction." ${ }^{\text {1 }}$

The twisting of the plot comes with the revelation of Sonmi's staged ascension, deeming her irrelevant, voiding her of personal determination, as she is enmeshed in the orchestration of "trial of the decade," with the purpose of making "every last pureblood in Nea So Copros mistrustful of every last fabricant." ${ }^{92}$ Because she is entrapped in the maze of self-construction prepared by the state on the hidden premise that no exit is to be encountered, her trajectory is simply traced as that of a lab rat, observed for the sterling pleasure of her master puppeteers. Her ultimate dismissal, revealed as another wheel in the mechanism of delusion, could be regarded as an interrogation of the practices of our post-truth era, whose politics are dictated by the same appeal to emotions and personal beliefs (as defined by the Oxford Dictionary), envisioning the possibility of such potential futures to collide.

In this "universe of simulation," the end of her narrative, with its revelation of the fictional nature of Cavendish's story, generates a domino effect: the previous narratives are laid bare as artful inventions, with the canvas that is imagined as an interplay between the real and the imaginary further blurring the distinction between the world inside the narrative and the one constructed as history, and also interrogating the myriad potentialities of our existence. As Hart compellingly warns, a distorted relation with alterity leads to estrangement and alienation. A "second fall and exile from Eden" for humanity, Nea So Copros collapses under the overwhelming weight of its moral sterility and vacuous leadership. In this rejuvenated society, the loss of technology stands as a warning against the potential effect of those tendencies which, if unsupervised, could lead to the collapse of society through auto-destruction.

\section{“Tho' a Cloud's Shape nor Hue nor Size Don't Stay the Same, It's Still a Cloud"}

hrough her death, Sonmi is seen as
further ascending to a "cloud atlas." Her spectral floating consciousness serves as proof of a self which goes beyond the 
crass materialist limitations of the liberal subject, empowering her definition as a postmodern subject, seen in its ambivalence as "both a coherent, unified whole and a contradictory, dispersed multiplicity." 93

Exiting her brief "simulacrum of life," Sonmi is reintegrated into the vortex of psyches which, rather than discriminating against her, kindly embrace the difference of the former drops of oceans vaporized into homogeneity. This plays beautifully into the trope of the desperately sought-after genuine human identity, the floating cloud in the endless atlas of souls. In this manner, the posthuman imagined by Mitchell goes beyond our vision of "embodied creatures, living inspecific times and places and limited by the biological, cultural, and historical inheritances that define us. ${ }^{94} \mathrm{He}$ imagines a "disembodied, free floating existence made possible in part by the near-instantaneous transfer of information from one point of the globe to any other." 95 Sonmi's transient existence in Nea So Copros continues to be valued by the inhabitants of the world to come, who revere her deified presence, empowering her with the attributes of divinity and immortal existence, as all the other narratives clash and collapse into fiction.

Therefore, if Hayles' nightmare is that of culture "inhabited by posthumans who regard their bodies as fashion accessories rather than the ground of being," 96 this condition of "disembodied immortality" is Mitchell's dream of species reconciliation and potential acceptance, reinstating the vision of the original ancestors, whose prophecy provides a mantric summary of the entire narrative:

If we believe that humanity may transcend tooth \& claw, if we believe divers races \& creeds can share this world as peaceably as the orphans share their candlenut tree, if we believe leaders must be just, violence muzzled, power accountable \& the riches of the Earth $\&$ its Oceans shared equitably, such a world will come to pass. ${ }^{97}$

In stark opposition to Huxley's grim conclusion, Mitchell seems to preserve his faith in humanity, in all its potentialities of evolution and transmutation, advocating hope for a more inclusive, redemptive future. After all, we are only humans, and in the reframing of our understanding stands the promise that the posthuman will develop a more permissive environment. Our lives may amount "to no more than one drop," with the "limitless ocean" rendering individuality insignificant, but the "multitude of drops" 98 postulates the image of a future freed from liberal humanist excesses, promising a more inclusive framework that will accommodate all possibilities for humanity and its futurity.

\section{Works Cited}

Allenby, Braden R. and Daniel Sarewitz, The Techno-Human Condition, London, MIT Press, 2011 Badmington, Neil, "Posthumanism," in Bruce Clarke and Manuela Rossini (eds.), The Routledge Companion to Literature and Science, New York, Routledge, 2011

Badmington, Neil, Alien Chic: Posthumanism and the Other Within, New York, Routledge, 2004

Baudrillard, Jean, Simulacra and Simulation, Ann Arbor, University of Michigan Press, 1994

Bostrom, Nick, "The Transhumanist FAQ: v 2.1," World Transhumanist Association (2003)

Braidotti, Rosi, The Posthuman, Cambridge, Polity Press, 2013 
Bukatman, Scott, Terminal Identity: The Virtual Subject in Postmodern Science Fiction, Durham, Duke University Press, 1993

Campbell, Norah, Aidan O'Driscoll, and Michael Saren, "The Posthuman: The End and the Beginning of the Human," Journal of Consumer Behaviour, 9.2 (2010), pp. 86-101

Carr, Nicholas, The Glass Cage: Where Automation Is Taking Us, London, Random House, 2015

Clark, Andy, Natural-Born Cyborgs: Minds, Technologies, and the Future of Human Intelligence, Oxford, Oxford University Press, 2003

Descartes, René, Discourse on Method and Other Writings, Baltimore, Penguin Books, 1960

Ezrahi, Yaron, Everett Mendelsohn, and Howard P. Segal (eds.), Technology, Pessimism, and Postmodernism, Amherst, University of Massachusetts Press, 1994

Fanon, Frantz, Jean-Paul Sartre, and Constance Farrington, The Wretched of the Earth, Vol. 36, New York, Grove Press, 1963

Fonseca, Isabel, Bury Me Standing: The Gypsies and Their Journey, New York, Vintage, 2011

Fukuyama, Francis, “Transhumanism,” http://foreignpolicy.com/2009/10/23/transhumanism/ (accessed December 29, 2017)

Fukuyama, Francis, Our Posthuman Future: Consequences of the Biotechnology Revolution, New York, Farrar, Straus and Giroux, 2003

Graham, Elaine L., Representations of the Post/human: Monsters, Aliens, and Others in Popular Culture, Brunswick, Rutgers University Press, 2002

Gupta, Chhanda and Debi Prasad Chattopadhyaya (eds.), Cultural Otherness and Beyond, Vol. 19, Leiden, Brill, 1998

Habermas, Jürgen, The Future of Human Nature, Cambridge, Polity, 2016

Halberstam, Judith M. and Ira Livingston (eds.), Posthuman Bodies, Bloomington, Indiana University Press, 1995

Hayles, N. Katherine, "Afterword: The Human in the Posthuman," Cultural Critique 53.1 (2003), pp. 134-137

Hayles, N. Katherine, How We Became Posthuman: Virtual Bodies in Cybernetics, Literature, and Informatics, Chicago, University of Chicago Press, 2008

Herbrechter, Stefan, Posthumanism: A Critical Analysis, London, A\&C Black, 2013

Hollinger, Veronica and Joan Gordon (eds.), Edging into the Future: Science Fiction and Contemporary Cultural Transformation, Philadelphia, University of Pennsylvania Press, 2002

Hurley, Kelly, "Reading Like an Alien: Posthuman Identity in Ridley Scott's Alien and David Cronenberg's Rabid," in Judith M. Halberstam and Ira Livingston (eds.), Posthuman Bodies, Bloomington, Indiana University Press, 1995, pp. 203-224

Hutcheon, Linda, A Poetics of Postmodernism: History, Theory, Fiction, London, Routledge, 2003

Huxley, Aldous, Brave New World, Stuttgart, Ernst Klett Sprachen, 2008

Ishiguro, Kazuo, Never Let Me Go, Stuttgart, Ernst Klett Sprachen, 2012

Istvan, Zoltan, The Transhumanist Wager, Futurity Imagine Media LLC, 2013

Kroker, Arthur and Marilouise Kroker (eds.), Critical Digital Studies: A Reader, Toronto, University of Toronto Press, 2008

Levinas, Emmanuel, Totality and Infinity, trans. A. Lingis, Pittsburgh, Duquesne University Press, 1969 Marcus, Greil, Lipstick Traces, Cambridge, Mass., Harvard University Press, 2009

Mill, John Stuart, The Greatest Happiness Principle - Utilitarianism, On Liberty E'The Subjection of Women, London, Madison \& Adams, 2017

Mitchell, David, Cloud Atlas, London, Hachette UK, 2008

Morris, Brian, Anthropology of the Self: The Individual in Cultural Perspective, Boulder, Pluto Press, 1994 Moylan, Tom, Scraps of the Untainted Sky: Science Fiction, Utopia, Dystopia, Boulder, Westview Press, 2000

Natoli, Joseph and Linda Hutcheon (eds.), A Postmodern Reader, Downsview, SUNY Press, 1993

Nietzsche, Friedrich, Thus Spoke Zarathustra, London, Jester House Publishing, 2016 
Onishi, Bradley B., "Information, Bodies, and Heidegger: Tracing Visions of the Posthuman," Sophia 50.1 (2011), pp. 101-112

Rex, Adam, The True Meaning of Smekday, New York, Disney Electronic Content, 2015

Suvin, Darko, Metamorphoses of Science Fiction: On the Poetics and History of a Literary Genre, New Haven, Yale University Press, 1979

Thacker, Eugene, "Data Made Flesh: Biotechnology and the Discourse of the Posthuman," Cultural Critique 53.1 (2003), pp. 72-97

Verbeek, Peter-Paul, Moralizing Technology: Understanding and Designing the Morality of Things, Chicago, University of Chicago Press, 2011

Williams, Raymond, Keywords: A Vocabulary of Culture and Society, London, Fontana Press, 1976

\section{ONLine Resources}

http://www.mirror.co.uk/tech/watch-sophia-sexy-robot-claim-7606152 (accessed December 12,2017) https://www.cnet.com/news/crazy-eyed-robot-wants-a-family-and-to-destroy-all-humans/ (accessed December 12, 2017)

http://www.businessinsider.com/meet-the-first-robot-citizen-sophia-animatronic-humanoid-201710/\#sophia-was-designed-in-audrey-hepburns-image-with-high-cheekbones-and-a-slender-nose-1 (accessed December 12, 2017)

http://uk.businessinsider.com/interview-with-sophia-ai-robot-hanson-said-it-would-destroy-humans-2017-11 (accessed December 12, 2017)

\section{Notes}

1. Katherine N. Hayles, How We Became Posthuman: Virtual Bodies in Cybernetics, Literature, and Informatics, Chicago, University of Chicago Press, 2008, p. 135.

2. https://www.mirror.co.uk/tech/watch-sophia-sexy-robot-claim-7606152 (accessed December 12, 2017).

3. https://www.cnet.com/news/crazy-eyed-robot-wants-a-family-and-to-destroy-all-humans/ (accessed December 12, 2017).

4. https://www.theverge.com/2017/11/10/16617092/sophia-the-robot-citizen-ai-hanson-robotics-bengoertzel (accessed December 12, 2017).

5. http://www.businessinsider.com/meet-the-first-robot-citizen-sophia-animatronic-humanoid-201710/\#sophia-was-designed-in-audrey-hepburns-image-with-high-cheekbones-and-a-slender-nose-1 (accessed December 12, 2017).

6. Ibidem.

7. http://uk.businessinsider.com/interview-with-sophia-ai-robot-hanson-said-it-would-destroy-humans-2017-11 (accessed December 12, 2017).

8. Andy Clark, Natural-Born Cyborgs: Minds, Technologies, and the Future of Human Intelligence, Oxford, Oxford University Press, 2003, p. 3.

9. Ibidem, p. 10.

10. Yaron Ezrahi, Everett Mendelsohn, and Howard P. Segal (eds.), Technology, Pessimism, and Postmodernism, Amherst, University of Massachusetts Press, 1994, p. 22.

11. Nick Bostrom, “The Transhumanist FAQ: v 2.1," World Transhumanist Association (2003), p. 4.

12. Friedrich Nietzsche, Thus Spoke Zarathustra, London, Jester House Publishing, 2016, p.204.

13. Aldous Huxley, Brave New World, Stuttgart, Ernst Klett Sprachen, 2008, p. 142.

14. Linda Hutcheon, A Poetics of Postmodernism: History, Theory, Fiction, London, Routledge, 2003, p. 57.

15. Joseph Natoli, and Linda Hutcheon (eds.), A Postmodern Reader, Downsview, SUNY Press, 1993.

16. Hutcheon, op. cit., p. 9. 
17. Peter-Paul Verbeek, Moralizing Technology: Understanding and Designing the Morality of Things, Chicago, University of Chicago Press, 2011, p. 114.

18. Tom Moylan, Scraps of the Untainted Sky: Science Fiction, Utopia, Dystopia, Boulder, Westview Press, 2000, p. 46.

19. Darko Suvin, Metamorphoses of Science Fiction: On the Poetics and History of a Literary Genre, New Haven, Yale University Press, 1979, p. 84.

20. Norah Campbell, Aidan O'Driscoll, and Michael Saren, "The Posthuman: The End and the Beginning of the Human" Journal of Consumer Behaviour 9.2 (2010), pp. 86-101.

21. John Stuart Mill, The Greatest Happiness Principle - Utilitarianism, On Liberty E The Subjection of Women, London, Madison \& Adams, 2017, p. 47.

22. Neil Badmington, Alien Chic: Posthumanism and the Other Within, New York, Routledge, 2004, p. 237.

23. Jean Baudrillard, Simulacra and Simulation, Ann Arbor, University of Michigan Press, 1994.

24. Stefan Herbrechter Posthumanism: A Critical Analysis, London, A\&C Black, 2013, p. 137.

25. Elaine. L. Graham, Representations of the Post/human: Monsters, Aliens, and Others in Popular Culture, Brunswick, Rutgers University Press, 2002, p. 33.

26. Ibidem, p. 116.

27. Badmington, Alien Chic, p. 204.

28. Istvan Zoltan, The Transhumanist Wager, Futurity Imagine Media LLC, 2013, p. 109.

29. Hutcheon, op. cit., p. 12.

30. David Mitchell, Cloud Atlas, London, Hachette UK, 2008, p. 177.

31. Bradley B. Onishi, "Information, Bodies, and Heidegger: Tracing Visions of the Posthuman," Sophia 50.1 (2011), pp. 101-112.

32. Hayles, op. cit., p. 136.

33. Judith M. Halberstam and Ira Livingston (eds.) Posthuman Bodies, Indiana University Press, 1995, p. 10.

34. Norah Campbell, Aidan O'Driscoll, and Michael Saren, op. cit., pp. 86-101.

35. Frantz Fanon, Jean-Paul Sartre, and Constance Farrington, The Wretched of the Earth, Vol. 36, New York, Grove Press, 1963, p. 132.

36. Hutcheon, op. cit., p. XI.

37. Emmanuel Levinas, Totality and Infinity, trans. A. Lingis, Pittsburgh, Duquesne University Press, 1969, p. 47.

38. Ibidem, p. 108.

39. Neill Scott, Terminal Identity: The Virtual Subject in Postmodern Science Fiction, Durham, Duke University Press, 1993, p. 322.

40. Levinas, op. cit., p. 47.

41. Ibidem.

42. Badmington, Alien Chic, p. 110.

43. Isabel Fonseca, Bury Me Standing: The Gypsies and Their Journey, New York, Vintage, 2011, p. 281.

44. Graham, op. cit., p. 20.

45. Ibidem, p. 29.

46. "The Transhumanist FAQ: v 2.1.," World Transhumanist Association (2003), p. 10.

47. Graham, op. cit., p. 23.

48. Hutcheon, op. cit., p. 23.

49. Brian Morris, Anthropology of the Self: The Individual in Cultural Perspective, Boulder, Pluto Press, 1994, p. 88.

50. Onishi, op. cit., p. 106.

51. Veronica Hollinger and Joan Gordon (eds.), Edging into the Future: Science Fiction and Contemporary Cultural Transformation, Philadelphia, University of Pennsylvania Press, 2002, p. 76.

52. Graham, op. cit., pp. 103, 23. 
53. Francis Fukuyama, "Transhumanism", http://foreignpolicy.com/2009/10/23/transhumanism/.

54. Arthur Kroker and Marilouise Kroker (eds.), Critical Digital Studies: A Reader, Toronto, University of Toronto Press, 2008, p. 55.

55. Norah Campbell, Aidan O'Driscoll, and Michael Saren, op. cit.

56. Hayles, op. cit., p. 38.

57. Badmington, Alien Chic, pp. 11-14.

58. Mitchell, op. cit., p. 222.

59. René Descartes, Discourse on Method and Other Writings, Baltimore, Penguin Books, 1960, p. 36.

60. Guy Debord, Society of the Spectacle, London, Chronos Publication, 1983, quoted in Greil Marcus, Lipstick Traces, Cambridge, Mass., Harvard University Press, 2009, p. 101.

61. Mitchell, op. cit., p. 334.

62. Mitchell, op. cit., p. 342.

63. Graham, op. cit., p. 160.

64. Eugene Thacker, "Data Made Flesh: Biotechnology and the Discourse of the Posthuman," Cultural Critique 53.1 (2003), pp. 72-97.

65. Baudrillard, op. cit., p. 88.

66. Ibidem.

67. Ibidem, p. 99.

68. Jürgen Habermas, The Future of Human Nature. Cambridge, Polity, 2016, p. 25.

69. Adam Rex, The True Meaning of Smekday, Disney Electronic Content, p. 129.

70. Mitchell, op. cit., p. 198.

71. Ibidem, p. 124.

72. Ibidem, p. 236.

73. Ibidem, p. 220.

74. Rosi Braidotti, The Posthuman, Cambridge, Polity Press, 2013, p. 23.

75. Hayles, op. cit., p. 12.

76. Chhanda Gupta and Debi Prasad Chattopadhyaya (eds.), Cultural Otherness and Beyond, Vol. 19, Leiden, Brill, 1998, p. 136.

77. Kroker and Kroker, op. cit., p. 46.

78. Ibidem.

79. Hayles, op. cit., p. 135.

80. Kroker and Kroker, op. cit., p. 13.

81. Herbrechter, op. cit., p. 137.

82. Mitchell, op. cit., p. 126.

83. Braden R. Allenby and Daniel Sarewitz, The Techno-Human Condition, London, MIT Press, 2011, p. 35.

84. Ibidem, p. 10.

85. Levinas, op. cit., p. 49.

86. Hutcheon, op. cit., p. XIII.

87. Kroker and Kroker, op. cit., p. 200.

88. Thacker, op. cit., p. 78.

89. Graham, op. cit., p. 37.

90. Ibidem, p. 37.

91. Mitchell, Op. cit., p. 535.

92. Ibidem, p. 336.

93. Hutcheon, op. cit., p. 175.

94. Hayles, op. cit., p. 394.

95. Ibidem.

96. Ibidem.

97. Mitchell, op. cit., p. 534.

98. Ibidem, p. 536. 